\title{
THE \\ MARCUS GARVEY \\ AND \\ UNIVERSAL NEGRO \\ IMPROVEMENT ASSOCIATION \\ PAPERS
}

SUPPORTED BY

The National Endowment for the Humanities

The National Historical Publications and Records Commission

The Ahmanson Foundation

The Ford Foundation

The Rockefeller Foundation

The UCLA Foundation

SPONSORED BY

The University of California, Los Angeles 



\title{
THE
}

\section{MARCUS GARVEY}

\author{
AND \\ UNIVERSAL NEGRO \\ IMPROVEMENT ASSOCIATION \\ PAPERS
}

Volume VI

September 1924-December 1927

Robert A. Hill

Editor

Barbara Bair

Associate Editor

Stephen Gil de Montes

Administrative/Production Assistant

University of California Press

Berkeley Los Angeles London 


\section{University of California Press \\ Berkeley and Los Angeles, California}

University of California Press, Ltd.

London, England

This volume has been funded in part by the National Endowment for the Humanities, an independent federal agency. The volume has also been supported by the National Historical Publications and Records Commission, the Ahmanson Foundation, the Ford Foundation, the Rockefeller Foundation, the UCLA Foundation, and the University of California, Los Angeles.

Documents in this volume from the Public Record Office are (C) British Crown copyright 1989 and are published by permission of the Controller of Her Britannic Majesty's Stationery Office.

Designed by Linda $M$. Robertson and set in Galliard type.

This volume has been typeset by Stephen Gil de Montes of the Garvey Papers project using the TYXSET software system supplied by TYX Corp., Reston, Virginia.

Copyright (C) 1989 by The Regents of the University of California.

\section{Library of Congress Cataloging in Publication Data}

Main entry under title:

The Marcus Garvey and Universal Negro Improvement Association papers
I. Garvey, Marcus, 1887-1940. 2. Universal Negro Improvement Association-History-Sources. 3. Black power- United States-History-Sources. 4. Afro-Americans-Race identity-History-Sources. 5. Afro-Americans-Civil rights- History-Sources. 6. Afro-Americans-Correspondence.
I. Hill, Robert A., 1943- . II. Bair, Barbara, I9s5- III. Garvey, Marcus, I887-1940. IV. Universal Negro Improvement Association

$\mathrm{E}_{185-97}, \mathrm{G}_{3} \mathrm{M}_{36} \quad 1986 \quad 305.8^{\prime} 96073 \quad 82-13379$

ISBN 978-0-520-06568-0

Printed in the United States of America

$\begin{array}{lllll}22 & 21 & 20 & 19 & 18\end{array}$

IO $\begin{array}{lllllll}9 & 8 & 7 & 6 & 5 & 4 & 3\end{array}$ 


\title{
EDITORIAL ADVISOR BOARD
}

\author{
Herbert APtheker \\ MARY Frances BERRY \\ JOHN W. BLASSINGAME \\ John Henrik Clarke \\ Edmund David CronoN \\ IAN DUfField \\ E.U. ESSIEN-UDOM \\ VINCENT HARDING \\ RICHARD HART \\ Thomas L. Hodgkin ${ }^{\dagger}$ \\ ARTHUR S. LINK \\ GeORge A. SHEPPERSON \\ Michael R. Winston
}




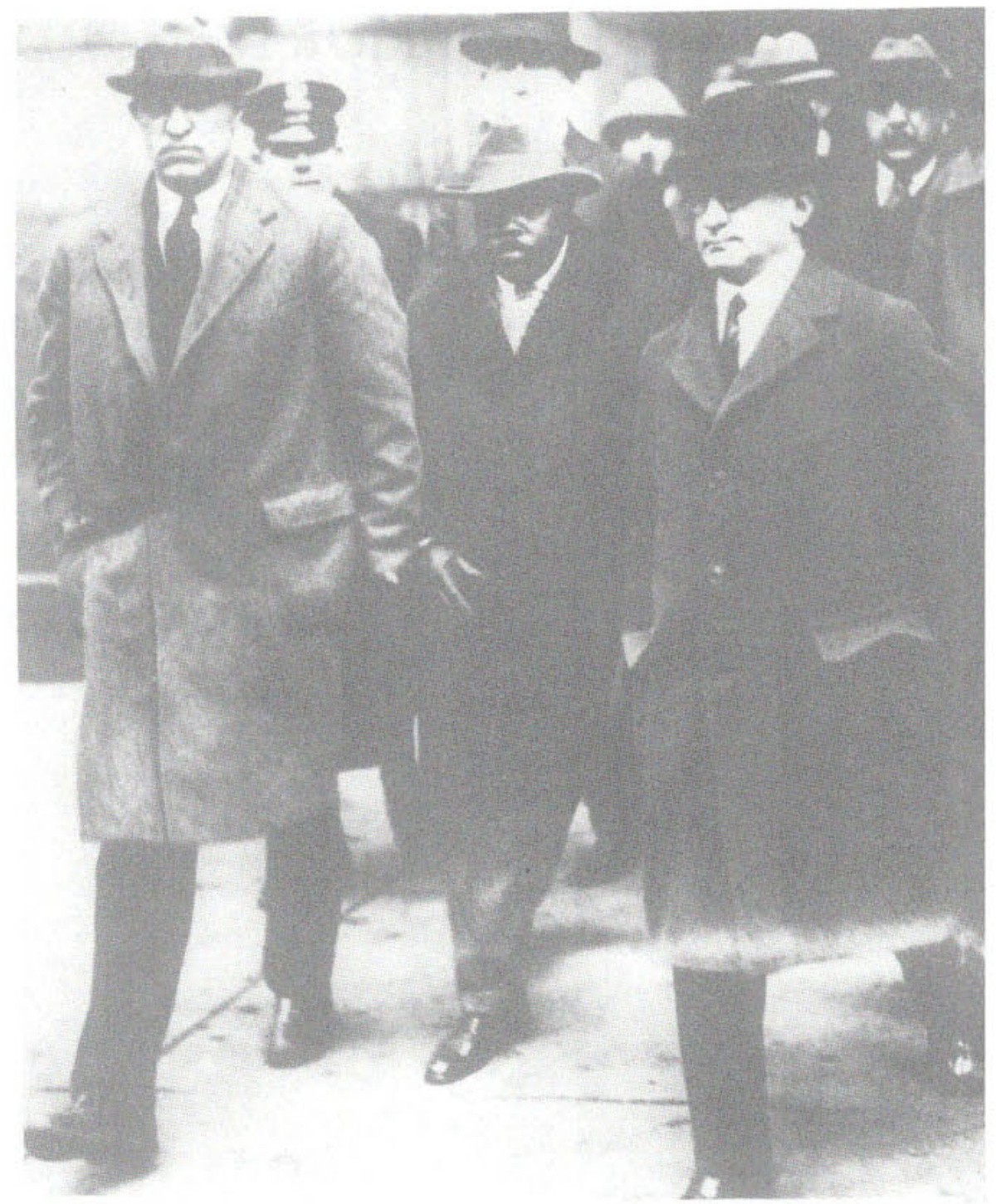

Marcus Garvey under escort to Manhattan House of Detention (Tombs prison), New York, February 1925 
In Memoriam
Tom W. Shick

I947-I986 
